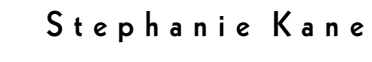

Pauline Greenhill

\title{
A Feminist Perspective on Bioterror: From Anthrax to Critical Art Ensemble
}

Not only is law enforcement incapable by itself of eliminating terrorism; but also, sometimes it may even be incorporated into a system of state terror.

-Alison M. Jaggar 2003, 175

n autumn 2001 anthrax was intentionally released through the U.S. mail.

With ancestry as ancient as goatskins and dispersal power enhanced by military lab technology, the deadly bacilli puffed through mail-sorting machines and seeped into the skin and lungs of postal workers sorting congressional mail. Symbolically fused with the intentional crashing of four passenger planes by terrorists wielding box cutters, the deliberate release of weaponized anthrax triggered renewed efforts to fight the socalled war on terror at home with a special mandate in the area of bioterror. ${ }^{1}$ Since then, basic democratic liberties have been traded for untenable and perverse illusions of safety and control in the polymorphous name of protection from terror.

Our critical analysis of the interactive fears and responses generated in and by the bioterror debate between 2001 and 2006 in the United States addresses the militarization of public health and the loss of human rights protections. Using a feminist approach that juxtaposes discourses from apparently disparate domains of art, law, and science, we examine the

Earlier versions of this article were presented at the American Society of Criminology panel "Consequences of September 11th" and at the American Anthropological Association forum "Bioterrorism, Epidemics, and the Future of Public Health" (both in San Francisco, November 2002); at the Department of Anthropology and School of Social Work, University of Michigan (March 7, 2003); at Boxcar Books in Bloomington, Indiana (March 10, 2003); and at Indiana University's Progressive Faculty Coalition Speaker Series (April 23, 2003). Kane thanks these audiences for discussion.

${ }^{1}$ In order to be used as a weapon, anthrax must be widely dispersible.

[Signs: Journal of Women in Culture and Society 2007, vol. 33, no. 1]

(C) 2007 by The University of Chicago. All rights reserved. 0097-9740/2007/3301-0004\$10.00 
rationales and effects of letting the military and private corporations infiltrate, profit by, and exert power over institutions responsible for the public's health. We reframe the debate by contrasting the government's response to perceived threats of extrastate terrorism with the historical normalization of domestic sexual terrorism, including anthrax-laced mail sent to reproductive choice clinics. To understand both the deeply submerged and the extraordinarily apparent gendered and racial logics that structure news, policy, and even scholarly communications in this arena, we examine a federal criminal case against an artist whose work is critical of bioengineering and bioterror industries; racial bias in the government's response to the risks experienced by postal workers-primarily African American - as a result of the deliberate, criminal release of anthrax from a government lab; and the government's measured response to the inadvertent importation of anthrax to New York City by an African dancer and drum maker. We conclude with recommendations for how government efforts might reorient toward best practices to promote the public's health and safety.

With unprecedented levels of interagency cooperation, new interlocking categories and procedures are linking institutions in diverse domains ranging from intelligence, the police, and the military to law and public health. Operating under the general rubric of homeland security, government agencies perpetuate the illusion that threats once associated only with violence beyond U.S. borders have emerged as newly local menaces requiring extreme solutions, justifiable no matter how draconian they may be. As Schuyler Henderson says, "By arguing that we are all potential victims . . . any cruelty can become reasonable in the name of self-defense" $(2005,187)$. Perpetrators are viewed as indistinguishable from other citizens: "Faced with such an enemy, every person can become a potential suspect hiding a terrible secret" (Henderson 2005, 187). Enhanced with the power of invisible molecular weapons, the image of the bioterrorist in particular encourages technology-savvy militarized responses to anticipated health crises while also obscuring the more pressing need, affecting vastly greater numbers of citizens, for investment in public health infrastructure and universal medical care.

"One of the less obvious casualties of the September 11 attacks has been a proper sense of history," writes Nicholas King. "The assumption that this event was sui generis, unfettered by context or precedent, has become an unassailable justification for American foreign and domestic policy" (King 2003, 433). And yet, neither domestic terrorism nor bioterrorism is new. Although disputes around definitions of terrorism remain 
highly charged, terrorism as violence and/or intimidation directed against a general population or specific group with ideological intent has a long history even within the territorial United States. Those marginalized by race, gender, and sexuality knew long before $9 / 11$ what it is like to feel unsafe at home, on their streets, and in their communities. Bombings, bioterror, and political assassinations all preceded $9 / 11$. Nothing remotely resembling a Department of Homeland Security resulted from the destruction of a government building in Oklahoma City, however, despite the rush to distance the perpetrators from ordinary Americans (see Arnault $2003,174)$. But ordinary Americans are implicated in the domestic terrorist attacks directed at services for women, such as the anthrax scares at pro-choice organizations and the harassment and murder of physicians performing legal operations. ${ }^{2}$

Those who work at or access services from reproductive choice clinics have long known terror and bioterror: "In mid-October 2001 more than 250 abortion clinics received letters containing a white powdery substance and the message: 'You have been exposed to anthrax.' . . . There has always been a reluctance to name these threats as a form of domestic terrorism, part of a war on women. Instead [each perpetrator] . . . is labeled as a lone nut-case" (Bell 2003, 479). The pervasive rape and violent abuse of U.S. women in their own homes has long been decried as a mode of sexual terrorism (Sheffield 2004), but these brutal attacks on hundreds of thousands of women annually have never produced a coordinated response comparable to the unleashing of Homeland Security forces armed with the invasive enforcement provisions of the USA PATRIOT Act. ${ }^{3}$ Though we do not in any way support the latter's extralegal

\footnotetext{
2 See esp. Baird-Windle and Bader (2001) and Mason (2002), although with respect to the 170 hate letters Planned Parenthood received after 9/11, Andrea Szalanski notes, "Unlike in the past, so far Planned Parenthood has been satisfied with the response from authorities" (Szalanski 2001-2, 32).

${ }^{3}$ In 1994, the National Crime Victimization Survey calculated that 433,000 rapes were committed in the United States. Whereas Federal Bureau of Investigation (FBI) estimates suggest that in the same year one of every 1,388 American woman was raped, the National Crime Victimization Survey indicates that one of every 270 women and one of every 5,000 men over the age of twelve was raped. According to the National Crime Victimization Surveys, the incidence of rape has been declining in the United States, falling from 433,000 in 1994 to 383,000 in 1999 and to 261,000 in 2000. During the same period, the FBI reports that the incidence of forcible rapes has been increasing, while other violent crimes have been decreasing (Greenfield 1997). The USA PATRIOT Act was passed by the U.S. Congress after $9 / 11$, greatly expanding government powers to obtain information about citizens without warrants or notification; Uniting and Strengthening America by Providing
} 
and nondemocratic form, a more concerted government effort would clearly be appropriate to the problem of wife abuse. A domestic terrorist arrested in 2003 for bombing a lesbian bar and two abortion clinics was not taken to Guantánamo Bay (see Mason 2005). Law enforcement is selective in instances of state-supported and state-ignored terrorism in everyday life.

When and under what conditions does the state respond to terrorism? How are particular threats elevated to the status of terrorism? What are the raced and gendered effects of the selective designation of certain acts as bioterror? By critically examining bioterrorism as the U.S. government's rationale for the massive buildup of military-bioengineering collaborations, we analyze and widen the debate taking place most intently among public health law and policy professionals and affected communities on the need for, and alternatives to, militarization in public health. We aim to understand both the deeply submerged and the extraordinarily apparent gendered and racial logics that structure news, policy, and other communications on the topic. Our analysis begins with that fateful autumn of 2001 but enters the bioterror debate from its margins via a disturbing federal legal case directed against peaceful, creative persons producing art as political dissent. ${ }^{4}$

\section{The Death of Hope (Kurtz)}

In the name of combating terrorism, laws may be passed that are so repressive or permit such discriminatory application that they facilitate terror by the state.

-Alison M. Jaggar 2003, 180

On the spring night that Hope Kurtz's forty-five-year-old heart stopped beating, "dial 9-1-1" literally brought the effects of 9/11 home. On the way to the bedroom where her body lay, emergency workers noticed art materials, including petri dishes containing bacterial cultures. Deeming her death suspicious, the paramedics called the police and the FBI, which

Appropriate Tools Required to Intercept and Obstruct Terrorism Act (USA PATRIOT Act), Public Law 107-56, 115 Stat. 272 (October 26, 2001).

${ }^{4}$ We could have chosen other examples of dialogues between feminism and bioterrorism; indeed, it is axiomatic to our thinking that these are not the only ones. We selected cases for the ways they use actual female, raced, or disabled bodies and artistic genres to show how even in apparently disparate and politically marginal locations the machines of state, bioterrorism, and patriarchy are trenchantly inserted. 
in turn invited the Joint Terrorism Task Force to invade her home and impound her body, her cat, and all artwork on the premises. Informing Kurtz's husband Steve that he was under investigation for bioterrorism, joint forces deployed from intelligence, military, and police organizations coordinated with upstate New York courts in launching their inquiries.

Hope and Steve Kurtz were founding members of Critical Art Ensemble (CAE). Steve Kurtz is also on the faculty at the State University of New York, Buffalo. Working in a variety of venues and media, including art galleries and the Internet, CAE uses performance art to present complex ethical questions about the science associated with the proliferating and unregulated industry of bioengineering. The group brings topics such as genetically modified foods, genetic technologies in human reproduction, and bioterrorism to the art community and wider public. ${ }^{5}$ At the time of Hope Kurtz's death, CAE was developing an art installation criticizing U.S. involvement in germ warfare. The project involved growing two forms of innocuous bacteria commonly used in high school lab experiments. The bacteria were obtained from Robert Ferrell, science adviser to CAE and principal investigator of the Human Genetics Laboratory at the University of Pittsburgh. In the two weeks following Hope Kurtz's death, other CAE members and collaborators began receiving subpoenas to appear before a grand jury investigating charges against Steve Kurtz lodged under the Biological Weapons Statute with provisions expanded by the PATRIOT Act. ${ }^{6}$ Accustomed to First Amendment protections of freedom of expression, neither the artists nor the scientist imagined that CAE's provocative mission and tactics would bring Homeland Security, operating through the U.S. criminal justice system, down upon their heads. ${ }^{7}$

Why was the power of the state unleashed in this instance of domestic

${ }^{5}$ For discussion of their work, see CAE (1998, 2000a, 2000b) and Schneider (2000). Joan Hawkins (2005) describes CAE's work: “They formed in 1987; originally from Tallahassee, they soon moved into the Eastern urban scene and became participants in a finde-siècle cultural formation. . . . They have made films, done theater, produced installations and written books. Along with other . . . artists like Kathy Acker, Amos Poe, Patti Smith, David Wojnarowicz and others, they share a commitment to formal and narrative experimentation, a view of the human body as a site of social and political struggle, an intense interest in radical identity politics, and a mistrust of institutionalized mechanisms of wealth and power."

${ }^{6}$ Expansion of the Biological Weapons Statute, H.R. 3162, 107th Cong. $\$ 817$ (2001).

${ }^{7}$ For discussion of the legal case, see Schneider and McKenzie (2004), Wilding (2004), Cox (2005), Hawkins (2005), Hirsch (2005), Pentecost (2005), and Schwabsky (2005). For an ongoing review, see Critical Art Ensemble Defense Fund, http://www.caedefensefund .org/faq.html. 
tragedy? How did Hope Kurtz's dead body come to be defined as suspicious? The home is a dangerous place for women in the United States. In cases involving the death of an apparently healthy woman in a heterosexual relationship, the first suspect is her male partner. Yet when women die in the home, police rarely take extraordinary notice, especially if there is no evidence or history of domestic violence. Moreover, Steve Kurtz was not initially arrested for suspicion of murder. The odd combination of a corpse and lab equipment in the home raised concerns.

When Steve Kurtz led the emergency team and police to Hope Kurtz's still body, the laboratory equipment triggered suspicion of bioterror that presumably cast the Buffalo home into a pathological interpretive framework. The PATRIOT Act reverses constitutional presumptions concerning the innocence of those accused of terrorism, and government agents apparently never entertained the possibility that Steve Kurtz might be innocent. Yet to get a warrant to search the home more completely, the FBI and prosecuting attorney never conveyed to the judge Steve Kurtz's explanation of why he had the harmless bacteria nor his position as professor and artist. On the contrary, they implied that he fit the profile of a bioterror suspect, reporting that he possessed a postcard with Arabic writing while omitting crucial details (that the postcard was a printed invitation to an exhibition at the Massachusetts Museum of Contemporary Art in which CAE was participating and that the Arabic was a caption beside one of several photographs to be exhibited).

Studies of organizational process indicate that once standard operating procedures of bureaucratic units are activated, it is enormously difficult to deactivate them, especially when there are important political interests at stake (Allison 1971). In the aftermath of the failure of the FBI to follow up on reports concerning suspicious pilot training for members of the September 11 terrorist team and the continuing failure to apprehend those responsible for the anthrax letters, members of the Joint Terrorism Task Force were highly motivated to avoid mistakes and to demonstrate their crime-solving acumen. This overzealousness, in combination with the extraordinary powers granted to law enforcement agencies under the PATRIOT Act, set the stage for the systematic abuse of Steve Kurtz's constitutional rights. It also shows that governments must be wary of themselves perpetrating terror upon their citizens, when they not only threaten lives but also significantly restrict people's sense of personal autonomy, producing fears about going to work, being deported, or facing criminal charges.

The coroner's autopsy report found that Hope Kurtz died of natural causes (heart failure). Unwilling to rely on the expertise of the local coroner, 
the FBI had U.S. military medical examiners review the autopsy, with no change in result. No link could be established between the corpse and the bacteria. No toxic substances and no public health threat were found. Nonetheless, the authorities continued their prosecution of Steve Kurtz and others connected to CAE. With no evidence, the bioterrorism charge had to be amended. Although the bacteria, Serratia marescens, is legally available from a number of suppliers such as the American Type Culture Collection (ATCC), a bioresource center that provides biological products, including bacteria, to researchers, the prosecutor brought charges of mail fraud and wire fraud relating to Ferrell's shipment of the bacteria to Kurtz. These charges deviate from routine practices in several important respects. According to Stan Cox, \$256 (the value of the bacteria Ferrell gave Kurtz) is below the amount that the U.S. Attorney's Manual (published by the Department of Justice) recommends when prosecutors consider bringing a dispute into a federal court. Moreover, appropriate cases for federal fraud charges ordinarily involve schemes to defraud a class of persons, or the general public, with a substantial pattern of conduct-not an isolated transaction between individuals involving minor financial loss to the victims (in this case, loss to the ATCC; Cox 2005).

In the grand jury indictment detailing how the organisms were obtained, Cox (2005) finds a dramatic shift in the court's language: the neutral terms biological materials or organisms are used to describe the policies of the ATCC and the university, but the term biological agent, associated in public discourse with weapons of mass destruction, is used to describe the actions of the collaborating scientist and artist. ${ }^{8}$ In the absence of a presumption of innocence and strenuous rules of evidence, small shifts in language help constitute Kurtz and Ferrell as menacing presences that must be contained.

Prosecutors say they are simply enforcing regulations designed to keep pathogens from getting into the wrong hands. But clearly fears associated with the threat of bioterrorism are contributing to skewed standards of prosecution. Consider, for example, that no one has been held accountable for an incident in which Cincinnati-based Meridian Bioscience sent out unexpected and mislabeled samples of the deadly flu virus $\mathrm{H} 2 \mathrm{~N} 2$ to five thousand laboratories around the world. Catastrophe was only averted by staff at the Microbiology Laboratory in Winnipeg, who discovered H2N2 in a sample from a woman patient (Davis 2005, 171-73). Similarly, no

\footnotetext{
${ }^{8}$ The case in question is The United States of America v. Steven Kurtz and Robert Ferrell, 04-CR-155E, May 2004 Grand Jury in the District Court of the United States for the Western District of New York.
} 
criminal investigation resulted when three people became infected with tularemia in the very Boston lab proposed as a site for a bioterror vaccine lab (Smith 2005). The routine use of the global mail system for sending and receiving packages containing deadly pathogens is a concern that dwarfs the CAE case and calls into question the excessive zeal in prosecuting it. Yet, despite pressing First Amendment issues and the strong basis for dismissal put forth by Kurtz's legal team, a federal judge decided that the case should proceed to trial.'

Steve Kurtz and CAE have used art as a mechanism of political critique. As scientifically informed and outspoken artists, they have used art space to dramatize ethical questions pertaining to the cloning of human embryos and the weaponizing of microorganisms. They have used their right to free expression to challenge powerful corporate and governmental interests, and their work has provoked angry responses. When CAE targeted Monsanto's main cash product, RoundUp Ready Plants, in its exhibitions at the Corcoran Gallery in Washington, DC, and at the World Information Organization in Amsterdam, Monsanto sent lawyers with cease-and-desist orders. Until Hope Kurtz's death, CAE regarded the condemnations and threats from police, lawyers, churches, political figures, and the FBI as part of the rough-and-tumble of public reactions to provocative political art (Hirsch 2005, 29-32). Indeed, in the past CAE has been encouraged by critical dialogue. The charge of bioterrorism, however, shifts the terms of debate. Fear of terrorism produced the PATRIOT Act, which authorizes the suspension of basic constitutional rights. Prosecutions initially undertaken under the provisions of the PATRIOT Act now leave Steve Kurtz facing the possibility of a twenty-year prison sentence even after the explicit charge of bioterrorism has been dropped. As state repression supplants First Amendment protections, American artists contemplate the chilling effect on critical work. Indeed, some have suggested that $9 / 11$ itself has caused artists to self-censor and the media to censor, contributing to the apparent death of satire, parody, and irony in general (Bilderback 2003; Youtt 2003).

Bioterrorism and sexual terrorism make strange bedfellows in this case. Domestic violence is a form of sexual terrorism that feminists have politicized, demanding state action to eradicate this pervasive and pernicious harm to women (Sheffield 2004). Yet in Hope Kurtz's death, the possibility of sexual terrorism was never seriously engaged. Unlike too many

9 The United States of America v. Steven Kurtz, 04-CR-155E-01. Action filed January 12, 2006. Because codefendant Ferrell is gravely ill, the case against him is being held in dormancy. 
others, her death had nothing to do with wife abuse. However, the event served as a pretext for a search to which Steve Kurtz, having nothing to hide, initially agreed. Hope Kurtz's death set interagency gears in motion, transforming a personal tragedy into a federal case. Long inured to neglect violence against women, the state had no compunction about using Hope Kurtz's corpse to track what it saw as bigger prey. Engendering a sense of constant public risk, bioterrorism captures the attention of public agencies in ways that domestic violence never has. Even in an instance where the evidence demonstrated that there was no bioterror threat, the resources of local, state, and federal governments have been deployed for remedial action. Ironically, this remedy is mere performance, lacking an action requiring redress.

Calibrating state expenditures in the Kurtz case illuminates disparate appropriations for gendered concerns. The state deploys vast resources against a suspected threat in the bioterror domain associated with male exploits while earmarking few resources for a vast, present, and manifest threat-sexual terror that endangers substantial numbers of women annually. The gendered lessons of the Kurtz case do not stop with comparative expenditures of state and federal energies and funds. The prosecution of Steve Kurtz illuminates the magnitude of the threat to constitutional rights created by the PATRIOT Act and serves as dire warning to artists and activists who dare challenge state power during the war on terror. The body of Hope Kurtz has lessons of its own. Used as pretext for what was once unlawful governmental action, then quickly superseded by state concerns with war, Hope Kurtz's corpse is a map of the contours of protection afforded women by a masculinist militarized state.

\section{Routine, spectacle, and the anthrax letters}

They tested the Capitol Hill police dogs before they tested the postal workers.

—Brentwood postal worker, cited in Blanchard et al. 2005, 493

Evidence from the government investigation suggests that an as yet unidentified person or persons working in or otherwise associated with the U.S. military facility in Fort Detrick, Maryland — a lab that may have been in violation of the Biologic and Toxic Weapons Convention-appropriated a small but significant supply of weapons-grade Bacillus anthraxis spores and mailed it to several people in the fall of 2001. This limited release presumably had political intent (Regalado, Fields, and Schoofs 2002; 
Broad, Johnston, and Miller 2003; Cohen, Gould, and Sidel 2004). At least one piece of toxic mail went through the sorting machines in the U.S. Postal Service's Brentwood Processing and Distribution Center in New Jersey before being opened by a staff person in Senator Tom Daschle's office on Capitol Hill on October 15. Although none of the apparent intended victims was even injured, eleven people developed inhalation anthrax. Of these, five died; two had cutaneous infections treated successfully with antibiotics. Thousands at risk of exposure were also treated prophylactically with antibiotics. Millions without possible exposure also took antibiotics. Public health laboratories that tested unknown powders were overwhelmed. Congress and the Postal Service were in disarray. Although this was a serious public health breach, it certainly did not indicate the effectiveness of anthrax as an agent of indiscriminate mass destruction. Furthermore, "without the existence of a US military laboratory, the materials for the release [of Bacillus anthraxis] would not have been available" (Cohen, Gould, and Sidel 2004, 1667).

With news of anthrax in the halls of Congress, fear of terrorism once again was concentrated on a biological mode of transmission that might be delivered daily to homes and businesses in the voluminous and variegated form of tainted mail. As in the war on terror more generally, it became difficult to distinguish between fact and fiction, reliable journalism and public relations. The blurring of fact and fiction in the public and governmental imagination of bioterror did not begin with this 2001 postal staging, however. Despite solid international agreement among nationstates not to deploy biological weapons, President Bill Clinton's belief in the need for elaborate defenses against germ weapons was inspired by a novel, The Cobra Event, which depicted an attack on Manhattan using a mixture of smallpox and cold viruses. As early as 1998, Clinton started pushing for stockpiles of vaccines as a crucial part of military preparedness. Fears fueled by fiction were speedily augmented by rumors of bioterror across the world; as rumor and reality intermingled, government policy shifted. Here is one example:

No one denies the threat of catastrophic terrorism, but the pace at which it has taken center stage as the prime threat to US security is almost as unnerving as the threat itself. In the media, Russian defectors talk alarmingly of new strains of untreatable anthrax and deadly cocktails of smallpox and Ebola; teenage hackers invade supersecret Pentagon computers; Aum Shinrikyo is said to be back in force, if not in action, after the Tokyo subway nerve gas incident; and three Texans are charged with plotting to assassinate President 
Clinton with a cactus needle coated with botulin flicked from a cigarette lighter. (Pringle 1998, 12)

The combination of rumors and real threats magnified by the mass media gave rise to calls to reshape public health priorities to address bioterrorism risks.

Crafting an appropriate public health response, however, is far from easy. A panorama of illnesses generate flu-like symptoms, which shrouds diagnosis of germ warfare in medical ambiguities. As a result of the evolutionary trick of latency, effects are manifest only after pathogens have infected a person and produced disease symptoms. As the Centers for Disease Control and Prevention (CDC) note on their Web site, the time span between exposure, infection, and symptom visibility varies with mode of transmission. ${ }^{10}$ This time lag makes detection of criminal intent in releasing biological organisms difficult.

Shortly after the anthrax letters were delivered, the Working Group on Civilian Biodefenses published a consensus statement in the Journal of the American Medical Association emphasizing that medical personnel in hospital emergency rooms, clinics, and laboratories would probably be the first to recognize when a flu-like illness results from unnatural causes, that is, from criminal intent. The working group pointed out that "the index case of inhalation anthrax in the 2001 attacks was identified because of an alert clinician who suspected the disease on the basis of large grampositive bacilli in cerebrospinal fluid in a patient with a compatible clinical illness, and as a result of the subsequent analysis by laboratory staff who had recently undergone bioterrorism preparedness training" (Inglesby et al. 2002, 2243). Thus treatment as well as the collection and analysis of forensic evidence depend on the knowledge and intuition of health workers. Given its members' role in the front line against bioterror, the working group admonishes health care workers to develop an "index of suspicion": "A patient (or patients) seeking medical treatment for symptoms of inhalation anthrax will likely be the first evidence of a clandestine release of $\mathrm{B}$ anthracis as a biological weapon. The appearance of even a single previously healthy patient who becomes acutely ill with nonspecific febrile illness and symptoms and signs . . . and whose condition rapidly deteriorates should receive prompt consideration for a diagnosis of anthrax infection. The recognition of cutaneous cases of anthrax may also be the first evidence of an anthrax attack" (Inglesby et al. 2002, 2242).

${ }^{10}$ See the Centers for Disease Control and Prevention Web site: http://www.bt.cdc.gov/ agent/anthrax/. 
The entire response system depends on individuals alert to the details that signal the index case: an odd patch of skin, a fevered brow. In fact, as we discuss below, a not-so-alert clinician missed the first cutaneous anthrax case. A delay in identifying an index case causes lags in the determination of species, strain, and remedy and in all subsequent public health and criminal justice bioterror responses. In the case of the anthrax letters, the forensic clue that eventually led investigators to look within the government's own labs was the bacteria's identification as the Ames Strain. Determining which precise genetic descendant of the Ames Strain was mailed led investigators to Fort Detrick (Weiss and Schmidt 2001).

Diagnostic and investigative response protocols depend first and foremost on infected individuals going to nurses and doctors who may discern and relay to the CDC the sometimes excruciatingly subtle differences in symptom combinations and contexts. Infected individuals are assumed to have sufficient information about bioterror risks to apprehend the need for immediate action. Yet in the case of anthrax, few people would possess the level of knowledge needed to assess risk. The flu-like stage caused by inhaled anthrax is only the first stage of the disease. The bacteria then allow a slight recovery before triggering the swiftly fatal, fulminating end. The small respite could cause a mortal delay in seeking medical care. According to the working group, the average onset of fatal symptoms, after which people cannot be treated successfully, happens in only four days. The victims of the anthrax letters waited an average of three-anda-half days before going to the doctor. In the United States, in the absence of a universal publicly subsidized health care system, financial considerations cause many people to delay seeking medical help, especially when symptoms appear to abate. Although the consensus statement is appropriately written in race-neutral and class-neutral language, in the United States, as the deaths from the anthrax letters make clear, questions of who gets medical attention, when, and at what standard of care do not result in race- or class-neutral answers.

The all-white, fully able U.S. congressional staff who were exposed to anthrax generally did not wait too long to see doctors. The fatal delays were with the employees of the Brentwood Post Office, 97 percent of whom were black and 19 percent of whom were hearing impaired. The general bias in the U.S. health care system against taking the health problems of people of color as seriously as those of people who enjoy white privilege was predictably extended into this faulty emergency response. Public health officials gave dangerously misleading advice, reporting that because the letters remained sealed they thought postal employees faced little risk. They failed to consider that the anthrax particles could be smaller 
than the envelopes' pores and could therefore seep out (Kersten 2004) and apparently did not think about the likelihood of torn or poorly sealed envelopes. ${ }^{11}$ Nor was the CDC alone in its flawed response. Postal officials knew that contaminated letters had passed through the system and yet waited several days before closing the facility. An employee group, Brentwood Exposed, has filed a lawsuit alleging that the Postal Service deliberately left them in harm's way during the anthrax attacks (Strohm 2003).

A detailed comparison of emergency response based on the perspectives of those exposed to anthrax highlights incidents contributing to fatal delays (Blanchard et al. 2005). A postal worker reported suspicious skin lesions to public health authorities on October 13. It is understandable that the first skin lesion did not signal an anthrax alert. Two days later, however, after the suspicious letter was opened in the Hart Senate Office Building and testing of that building had begun, emergency protocols should have been operative in the post office that had delivered the letters. The CDC did not pay even an initial visit to the post office until six days after the skin lesions were reported. Two postal workers died in the two days following. Selective attention resulted in selective detection, which resulted in selective intervention and a racially skewed result. ${ }^{12}$

The tools to decipher this mystery were available. Consider, by comparison, that the anthrax hoax at the reproductive choice clinics in October 2001 was discovered quickly. Under threat since 1989, women's reproductive health clinics have developed handling protocols. Mail is "routinely opened in a sealed room by gloved handlers." These safeguards are in place because anthrax threats are "'business as usual' for abortion providers" (Bell 2003, 492; see also Baird-Windle and Bader 2001; Mason 2002). The interplay of real threats (powdered anthrax as well as conventional weapons such as bombs and guns) and hoaxes (innocuous powders) all combine to create a sense of pervasive attack. Falling below the threshold of state security priorities, women's medical facilities employ universal precautions to protect themselves. Attacked by domestic sexual terrorists, abortion providers resist by performing surveillance routines to provide some measure of safety within clinic walls and doctors' homes

\footnotetext{
${ }^{11}$ It must be said that the CDC's communication failures transcended race and class differences to some extent; the agency's incompetence was questioned by staff in both the Hart Senate Office Building and the post office (Government Accountability Office Report GAO-04-239, cited in Inglesby et al. 2002).

${ }^{12}$ The first ten cases of inhalation anthrax included four black men, two black women, one Hispanic man, and one South Asian woman. All but one, a white male photojournalist, were working-class handlers of mail or hospital supplies (Jernigan et al. 2001; see also U.S. Commission on Civil Rights 2002).
} 
and by pressing for criminal prosecution of those responsible. In the underfunded realm of women's reproductive health, bioterror has been quietly normalized and safety procedures made routine. Yet in the well-funded state institutions charged with responsibility to fight the war on terror, misinformation and excessive delays contributed to the endangerment and death of working-class postal workers of color and disability (hearing impaired).

Attentiveness to the needs of highly paid Senate staff and elected officials stands in marked contrast to the callous disregard for the well-being of postal workers, creating the impression that the people in charge of government agencies acted as though some were not worth saving. Postal workers said that they were reminded of the Tuskegee syphilis experiments (1932-72), when hundreds of poor black men in Alabama were prevented from getting treated with penicillin while doctors followed their cases without sharing with them the diagnosis of syphilis. ${ }^{13}$ One Brentwood postal employee told Janice C. Blanchard and colleagues $(2005,492)$ : "People kept saying they're using us as guinea pigs. We heard all kinds of things. . . . They came back down to the post office every so often with questionnaires, you know, to fill out. They were very interested, but it was only for research." Another said: "I asked [the CDC representative] what made them want to give us the vaccine, what constituted us needing it. And they talked about a study with some monkeys how they had 3 subject groups. . . . One group didn't get any treatment. . . . So I figured for all I know [we] could have been the ones who didn't get any [treatment,] and they were using us" (Blanchard et al. 2005, 492).

Depending on the actual form of bioterror, strongly gendered and raced effects can be anticipated in terms of those who will care for those affected, beginning with emergency room medical personnel and ending with the women who will predictably, in the vast majority of cases, provide the bulk of continuing care for those who fall ill. As a suggestive (if fortunately not statistically significant) example, all four health care workers who died as a result of the (nonbioterror) SARS outbreak in Toronto, Canada, in 2003 were people of color, and three-Adela Catalon, Nelia Laroza, and Tecla-Lai Yin Lin-were women (SARS Commission 2007). In 2002, the journal Nursing Management announced voluntary smallpox vaccination for emergency medical personnel "because of the threat of bioterrorism" $(2002,32 \mathrm{~F})$. Many first responders were reluctant to volunteer for the

\footnotetext{
${ }^{13}$ The history of racial stigma has influenced the effectiveness of public health measures in, e.g., the AIDS pandemic (Kane and Mason 2001) and the hantavirus outbreak in the southwestern United States (Garrett 1994, 528-49).
} 
vaccination. They were right to be cautious; vaccinations are never without risk, but the smallpox vaccination is dangerous not only to the recipient but also to those with whom she or he comes in contact (Landers 2002).

\section{Dual use of the technological infrastructure to respond to bioterror}

Bureaucracies fight catastrophe (real and imagined) with routine, which drives them to fortify and elaborate even poorly designed and regulated systems. ${ }^{14}$ The first phase of the twenty-first-century antiterror crusade involved linking basic communication infrastructure among government agencies through the Federal Emergency Management Agency, public health agencies, law enforcement, and intelligence at local, state, and federal levels (see, e.g., Peterson 2002). The communication web encircling the skies, seas, and land is deemed essential to thwarting mass disasterswhether natural, industrial, or criminal in origin. Together with radio and television, the Internet relays emergency instructions to first responders and the public. While the public has accepted the need for disciplined responses to emergency warnings pertaining to fire and weather, mass communication may not be as effective and clear in reaching at-risk people in a bioterror event. Hurricane Katrina has certainly shown how information and communication infrastructures are insufficient.

Emergency overload can contribute to massive failure of computer networks and interlocking government systems. During the October 2001 anthrax scare, the CDC's Web site, the central information source for the United States and many other countries, crashed-twice. The CDC responded by creating a new bioterrorism Web page with accurate information about how to prepare for and deal with exposure to biological, chemical, or radiological agents, a site designed as a reference for medical, laboratory, and public health professionals and the general public. By the following January, the main site and new link boasted over 9 million visits, outpacing all other government Web sites (CDC 2002).

Cyberterrorists have also threatened to disrupt computer networks that control vital national communications. Possible targets include the 911 emergency telephone system, air traffic control and public transportation networks, and financial networks. Specific targets include the CDC and FedWire, a money-clearing system controlled by the Federal Reserve Board (GovExec.com 2002).

The tension between appropriate and subversive, constructive and de-

${ }^{14}$ Consider the exceptionally dangerous Meridian Bioscience H2N2 and Boston tularemia cases discussed above. 
structive uses of the Internet is often referred to as "dual use," a cause of increasing concern to those orchestrating the war on terror. ${ }^{15}$ In his annual report to the president and Congress, former defense secretary Donald Rumsfeld warned that increasing availability of commercial, offthe-shelf technology to terrorist groups and enemy states means that it may be used to develop "offensive information operations" that could disrupt military information systems, such as those that enable U.S. troops to engage in "network-centric" warfare with other combat units and foreign allies (Peterson 2002). Concerns about dual use also surface in the realm of bioterrorism: "Greater understanding and control over infectious diseases inevitably leads to greater opportunity for transforming those diseases into weapons" (King 2003, 438). More particularly, the Internet disseminates information on biological agents and technology, making bioproduction capabilities accessible to individuals with limited experience- to amateurs and to terrorists. According to the Central Intelligence Agency's (CIA) National Intelligence Council, "the bioterrorist's laboratory could well be the size of a household kitchen, and the weapon built there could be smaller than a toaster" (quoted in Nartker 2005).

There is no question that the problem of dual use makes tracking and identifying bioterrorists much more difficult. Yet quite apart from this difficulty, the CIA's recourse to domestic and feminized metaphors-the kitchen, the toaster - in this particular discourse signifies a new female gendering of the bioterror threat. In the CIA's view, homeland security must shift its attention from the public world, long associated with men, to the private sphere, women's domain. The hermeneutics of suspicion penetrates the interior world of the household, subjecting comforting daily routines like food preparation to surveillance and control. Invasive practices that abridge privacy rights can be legitimated precisely because benign

15 The dual-use metaphor builds on deeply embedded forms of binary logic encoded in public discourse. Stretched to a variety of contexts, it signals opposing forces, purposes, or social identities. Although expansive in rhetorical application, it is misleadingly premised on the existence of coherent, distinct enemies of (and among) the citizenry. To disrupt such binary formations, it is important to note that the Internet can be used for manifold purposes, not least of which is use as an activist art space. For example, CAE's works are posted on its Web site. "Marching Plague," a performance piece carried out in a boat off the British Isle of Lewis, involves artists brewing a harmless bacterial broth of Bacillus subtilis, which is then thrown from the boat toward guinea pigs floating on a platform a mile away. The artists mimic British military experiments carried out in $1952-53$ to determine if the plague could be used as a tactical ship-to-ship weapon. In this work, CAE claims to show that germ weaponry is not only a stupid idea but an impractical one. Such performance pieces constitute a critical metacommentary that engages militarized discourse in useful ways. 
instruments like stoves and microwave ovens become sources of danger. Invisible enemies within the homeland and the home must be rooted out by any means necessary. Homely domestic metaphors provide the rationale for extraordinary state intervention, even if these interventions are highly unlikely to accomplish their stated objectives. Equality of suspicion and surveillance is not what feminists have been fighting for.

\section{Dancing with anthrax: A measured emergency response}

In a period of heightened terrorist alert, expensive bioterrorism protocols can be triggered by any suspicious bit of white matter out of place. Like a fire alarm, hyperattention can be a seductive lure to malicious and nonmalicious tricksters. While jokes about pathogen paranoia have become a part of popular culture, false anthrax scares have become a drain on the budgets of local governments. Yet the search for real and faux bioterrorists does not exhaust the possibilities of bioterror. Accidental intersections of nature and culture can also pose biohazardous threats with real epidemiological consequences. A case in point involves the human use of goatskins, which carry naturally occurring anthrax spores.

In early December 2005, Vado Diomande, a forty-four-year-old dancer in New York City, traveled home to Tousingha, a village in Africa's Ivory Coast. His journey took him by way of the city of Abidjan, where he bought five dried goatskins to make popular drums known as djembes. ${ }^{16}$ Diomande brought the skins through the Abidjan airport, although he failed to mention them to officials when he entrusted them to the plane's cargo hold. Landing at John F. Kennedy Airport in New York on December 20, he also failed to declare the hides to U.S. Customs. Had he done so, the new surveillance routines of the network of Customs and Border Protection inspectors would have been triggered. ${ }^{17}$

Passing through the airport unnoticed, the skins were brought by van to an eight-story Brooklyn warehouse containing recording and art studios in addition to storage space. Details concerning the days following Diomande's return to the United States are fuzzy. He spent time at the Greenwich Village apartment that he shared with his wife. It is unclear from newspaper accounts how or when he cleaned the skins and whether he did so in Tousingha or in the warehouse where he stretched the hides

\footnotetext{
16 This section is based on Baker and Santora (2006), Chan (2006), and Goldman (2006).

17 The network of inspectors, drawn together from the Immigration and Naturalization Service and the Department of Agriculture's Animal and Plant Health Inspection Service, is now part of the troubled Department of Homeland Security.
} 
over the wooden djembe bases. The skins are described as untreated. (Bleach, properly applied, would have killed anthrax spores.) After stretching the skins, Diomande stripped off his clothes, put them in a hamper, and showered. He became ill shortly thereafter.

The minor spectacle of Diomande's collapse on Thursday, February 16, 2006, following his performance at Mansfield University, brought this instance of accidental importation and dispersion of Bacillus anthraxis to official attention. Diomande was hospitalized immediately. By Tuesday, February 21, the Pennsylvania Department of Health and the CDC positively confirmed anthrax in his blood. By Wednesday, the case was made public, and authorities got to the warehouse, where only one of the four skins, stretched over a drum, remained. The other three had already been sold as drums. New York City police cordoned off sections of the apartment, the warehouse, and a third building in Crown Heights, where a man was reported to have had contact with the skins. The federal investigating team, including four industrial hygienists, two epidemiologists, one biologist, and one laboratory scientist, collected samples from Diomande's apartment and van while FBI agents took samples from the warehouse. None of the searches revealed any evidence of anthrax production. Diomande was treated successfully for inhalation anthrax, as were the seven other people who might have had contact with the spores, including Diomande's wife, who had accompanied him to his performance and remained by his side. No one else became ill.

Despite the lack of customs inspection to trigger routine detection and prevention procedures at the borders, the consequent infectious collapse was duly noticed and acted upon. Even after almost two months of bacterial presence, once response routines were triggered, they workedtestimony to the improved expertise of the CDC and, along with the anthrax letters to Congress, which despite massive government bungling resulted in relatively few actual cases, testimony to the fact that anthrax is not an effective mass weapon.

Diomande's case highlights the importance of cultural flows in the epidemiology of global port cities. The tension between complete surveillance, on the one hand, and the efficient flow of goods and people, on the other, cannot be readily resolved (Khalid 2005). Like the scientists who, for convenience, routinely deviate from the legal technicalities in sending biological organisms through the mail, international airline passengers avoid perceived delays or obstacles associated with declaring animal and plant purchases to customs officials. Recognizing that the dancer's actions were akin to those of many traveling consumers, the investigating team categorized the incident as an accident. Although civil 
charges may be filed, there will be no criminal charges. The ancient scourge of anthrax appeared and disappeared with yet another contemporary twist. In Diomande's case, government employees manifested efficient interagency cooperation in the aftermath of an international border crossing by microbiological invaders unintentionally carried in by a traveler. Appropriate medical care was provided, and any threat to public health was contained.

\section{And yet . . .}

Militarization can come in many guises. It can ride on the back of a worthy cause.

—Cynthia Enloe 2000, 32

The present expansion of bioterrorism preparedness programs will continue to squander health resources, increase the dangers of accidental or purposeful release of dangerous pathogens, and further undermine efforts to enforce international treaties to ban biological and chemical weapons.

-Hillel W. Cohen, Robert M. Gould, and Victor W. Sidel 2004, 1667

One lesson from the past century that should guide any national response to terrorism-and the conception of public health in general-is that public trust in public health recommendations depends upon respect for human rights. . . . Protecting human rights is good for public health.

-Wendy K. Mariner 2003, 530-31

In the heightened security regime of the so-called war on terror, three cases involving biological materials produced three markedly different governmental responses. How should these examples be interpreted-as evidence of a learning curve through which government agencies are gaining the requisite expertise to respond appropriately to potential threats to public health, or as purely idiosyncratic responses by diverse officials acting on their suspicions and intuitions? Without far more systematic data, it is impossible to derive generalizable conclusions from these three episodes. And yet, these differing scenarios raise a host of important policy questions about governmental responses to perceptions of threat and about the militarization of public health.

One key question involves the fundamental meaning of public health. It is crucial to distinguish between "the public's health," which entails versatile, locally organized practices and principles to foster personal health and autonomy, disease prevention, and treatment, and "Public Health," 
which Lawrence O. Gostin and his associates (2002) believe requires centralized authorities with emergency powers to manage vaccines, medicines, hospital beds, quarantines, and morgues and to coerce if necessary those individuals who refuse to comply with the dominant representation of the common good. ${ }^{18}$ Discourses on bioterror preparedness tend to conflate these disparate meanings, suggesting that concern with the latter will promote the former. The first two case studies in this article raise concerns about the validity of that assumption.

The Kurtz case and the case of the anthrax letters illuminate an expanding array of semisecret, public-private, medical-military partnerships that require vast expenditures of funds for their operations. In a world of limited resources, monies expended on bioterrorism preparedness are diverted from funding for basic public health infrastructure and health care systems, producing markedly inequitable outcomes, especially for the poor, who are most dependent on the public health system. Recent federal legislation highlights these distributional inequities. When the U.S. Senate in a 99-0 vote joined the House of Representatives in approving "Project BioShield," legislation funding research, production, and stockpiling of vaccines and antidotes for bioterror agents, it allocated billions of dollars to pharmaceutical companies while simultaneously relaxing regulatory controls and eliminating liability for the production of harmful or ineffective vaccines (Holland 2004).

Exclusive focus on bioterror preparedness tends to promote excessive confidence in the power of scientists to create and control microbial weapons while converting them to beneficial uses. Yet that confidence elides a host of historical, environmental, and political issues. In the 1950s and 1960s, before international conventions brought a halt to biological and chemical weapons production, scientists at Fort Detrick produced more than three tons of microbes, including anthrax, tularemia, and brucellosis, precisely the same lethal biological weapons that Americans were told they had to invade Iraq to destroy (Regis 2004). "Biodefense for the 21 st Century," a classified document prepared by the George W. Bush administration, proposes that the Defense Department build a national bioforensics analysis facility at Fort Detrick, the very source of the intentional anthrax release in October 2001 (Webb 2004). ${ }^{19}$

Despite unresolved questions concerning culpability for this real act of

\footnotetext{
${ }^{18}$ Paula Allen-Meares, dean and Norma Radin Collegiate Professor of Social Work at the University of Michigan, referred to institutional differences between "public health" and "the public's health" (personal communication, March 7, 2003).

19 The budget for the new Fort Detrick lab is \$128 million (Warrick 2006).
} 
bioterror, the government is confident that the military can ensure a safe transition from producing germ warfare agents to producing germ warfare vaccines, when the latter requires the production, shipment, and storage of the former. Despite a long history of accidents, the government is confident that the military will be able to control accidental and intentional criminal releases (see Cohen, Gould, and Sidel 2004; Regis 2004; Thacker n.d.). Nor is Fort Detrick the only proposed site for bioterrorism preparedness operations. A number of Biohazard Level 4 and 5 research sites may be scattered throughout the country, including in the middle of dense urban neighborhoods (Byravan and Krimsky 2003). Beyond critical questions concerning public safety should there be accidental or criminal release of such toxins, the proliferation of these facilities raises issues of international law. The Bush administration claims that this research complies with the Biological Toxin Weapons Convention, which outlaws the manufacture of biological weapons, but that treaty makes no distinction between defensive and offensive intentions. ${ }^{20}$

As interagency cooperation develops in bioterror efforts, public health funds are disbursed across an array of institutions for purposes at some remove from the public's health. Consider, for example, the bioterror preparedness program BioSense, a plan that moves money from budgets in states where bioterrorism is not deemed a threat to locations where it is, to provide funds for certain services in the event of an attack. BioSense provides funds to post offices to deliver medicine. It also provides funds for public health agents to detain infected and exposed persons in federal quarantine, expanding the prison-industrial complex with what in effect will be temporary medical prisons. A broad assortment of public health advocacy groups, including the American Public Health Association, opposed shifting funds away from states with "ongoing areas of vulnerability" (McGlinchey 2004). In developing their arguments against BioSense, however, public health advocacy groups adopted the terms of debate set by military planners. Areas of vulnerability is not the term in which public health professionals typically describe the health needs of the U.S. population. Preoccupation with bioterror preparedness contributes to a militarization of public health discourses even among those explicitly opposed to specific government public health plans.

As the boundaries blur between measures to enhance the public's health

\footnotetext{
${ }^{20}$ Convention on the Prohibition of the Development, Production and Stockpiling of Bacteriological (Biological) and Toxin Weapons and on Their Destruction, April 10, 1972, 26 U.S.T. 583, 1015 U.N.T.S. 163. See also David Fidler, Indiana University School of Law professor, quoted in Warrick (2006).
} 
and measures to promote militarized public health, those most in need of public provision of medical care lose ground. The specter of anthrax and other potential microbial weapons displaces concern in minds and budgets with the prevention and management of diseases endemic to poverty with known treatments or cures (e.g., AIDS, cholera, dysentery, malaria, measles, and multidrug-resistant tuberculosis).

The social control measures associated with emergency powers exercised in periods of crisis do not respect individual rights. As the Kurtz case so graphically demonstrates, individual rights and constitutional protections may be jettisoned when overzealous government agencies seek to protect the public from the threat of bioterror. As an orientation guiding law and policy, fear has corrosive effects. Authorizing state officials to use coercion to enforce compliance with government conceptions of the public good is unlikely to foster respect for individual health and autonomy. Nor is it likely to produce policies that enhance public safety. By increasing the number of facilities producing microbial agents in order to develop vaccines, the government also increases the possibility of lethal accidents. Militarization of public health is a fear-based response to bioterror risk. It should never be confused with best practices in the provision of public health. Emergency prevention and management should be aspects of public health planning, but they should not become a substitute for sustained efforts to improve and extend health care and communication infrastructure and expertise to benefit all members of the public, whose health needs vastly exceed threats of bioterror.

The three cases discussed in this article do not represent a totality of response possibilities. But they show how official discourse and action are always performed on a stage made uneven by social inequality. No matter the extent of education and exercise, protocols for defining certain situations as risky, whether they involve crime, illness, accident, useful science, performance art, or some combination of the above, are dependent on interpretation. To the degree that social actors in positions of power and responsibility allow their conscious or unconscious racial, gender, and/or political biases to affect their decision making, the protocols' implementation will be idiosyncratic and subject to abuse. The narrower and more blurry the boundary between the institutionalization of measures to enhance the public's health, on one hand, and a militarized public health colossus, on the other, the greater the destructive potential of current bioterror initiatives, both for those whose identities and social locations render them most susceptible to official procedures' vicissitudes and for society more generally.

Procedures - what must happen, and how-will vary tremendously. No 
grand plan can apply equally well to mass emergencies as different as Ebola or tuberculosis in New York, United States, or in Tousingha, Ivory Coast. Nevertheless, if laws and policies are not applied equitably and justly, they enhance the mechanisms of antidemocratic forces. As the AIDS epidemic has taught, effective public health law, even in a bioterror crisis, must put the protection of infected persons' human rights at the center (Burris, Dalton, and Miller 1993): "Public health is not our only social value. And government is not always as beneficent as public health officials and advocates may assume. If public health fails to take human rights into account, it will too often view social policy choices as a conflict between health and liberty" (Mariner 2003, 551; see also Annas 2002). Just as the dominant public health model rejects the criminalization of HIVpositive persons even though among them a malicious intentional infector may walk (Kane 1998), so that model should resist militarization as a response to fear of infected/infecting mass avengers.

It is crucial to critically and holistically examine the practical and ethical implications of all technological innovations that may adversely affect living organisms and environments, not only in relation to bioterror but also in relation to global biosafety and biodiversity issues (e.g., biopiracy, genetic and nuclear engineering, and the use of contaminated medical products). Fear of the intentionally infected and infecting avenger must be coupled with a healthy skepticism about the bioterror paradigm. Investment in the bioterror industry should not proceed without larger investments in human and environmental health. Bioengineering and chemical production industries, civil and military, should be required to abide by precautionary principles when introducing genetic alterations and toxic substances into the air, water, and earth. It would be foolish to leave food and water supplies unprotected from terrorist attack (see, e.g., Francis 2005; Meinhardt 2005), but neither should governments and citizens continue to allow damage from toxic industrial pollution in profit's name.

Analysis of past emergencies shows that ordinary people generally behave rationally if they have survival tools. ${ }^{21}$ As an orientation guiding law and policy, trust remains more pragmatic than fear. Rather than pouring public funds into secret germ-production facilities, a feminist perspective calls for improving and extending health care and communication infra-

\footnotetext{
${ }^{21}$ See expert in bioterrorism, anthropologist, and senior associate at the Center for Biosecurity at University of Pittsburgh Medical Centre Monica Schoch-Spana's December 14, 2006, briefing to the Democratic Caucus of the House Committee on Science, which presents plans for participatory governance in health emergencies (Nuti 2006).
} 
structure and expertise to benefit all, regardless of class and citizenship status. Emergency prevention and management should be an aspect of, not a substitute for, this global survival project-for, although we focus here on events in the United States, our discussion's implications are global in scope. People free to be creative and critical, who engage in dialogue and performance across areas of expertise, disciplines, and social and political identities, are most likely to make a safer society possible. Activism, art, and good science, including social science, are essential elements of a successful public move to impose limits on or-dare we hope-derail the apparently mindless expansion of the bioterror industry. Artists, scientists, those in the healing professions, those in the law, and of course feminists who work toward a grounded, egalitarian vision of the public good must with haste engage vigorously in the bioterror debate.

Departments of Criminal Justice and Gender Studies

Indiana University (Kane)

Department of Women's and Gender Studies

University of Winnipeg (Greenhill)

\section{References}

Allison, Graham T. 1971. Essence of Decision: Explaining the Cuban Missile Crisis. Boston: Little, Brown.

Annas, George J. 2002. "Bioterrorism, Public Health, and Civil Liberties." New England Journal of Medicine 346(17):1337-42.

Arnault, Lynne S. 2003. "Cruelty, Horror, and the Will to Redemption.” Hypatia 18(2):155-88.

Baird-Windle, Patricia, and Eleanor J. Bader. 2001. Targets of Hatred: Anti-abortion Terrorism. New York: Palgrave.

Baker, Al, and Marc Santora. 2006. "Where Tracking Anthrax Begins with the Honor System.” New York Times, February 24, Bl.

Bell, Diane. 2003. "Good and Evil: At Home and Abroad." In After Shock: September 11, 2001: Global Feminist Perspectives, ed. Susan Hawthorne and Bronwyn Winter, 474-92. Vancouver: Raincoast.

Bilderback, Walter. 2003. "The Naomi Wallace Festival and 9/11." Consciousness, Literature, and the Arts 4(3). http://www.aber.ac.uk/cla/archive/bilderback .html.

Blanchard, Janice C., Yolanda Haywood, Bradley D. Stein, Terri L. Tanielian, Michael Stoto, and Nicole Lurie. 2005. "In Their Own Words: Lessons Learned from Those Exposed to Anthrax." American Journal of Public Health 95(3): 489-95. 
Broad, William J., David Johnston, and Judith Miller. 2003. "Subject of Anthrax Inquiry Tied to Anti-germ Training." New York Times, July 2, Al.

Burris, Scott, Harlon L. Dalton, and Judith Leonie Miller, eds. 1993. AIDS Law Today: A New Guide for the Public. New Haven, CT: Yale University Press.

Byravan, Sujatha, and Sheldon Krimsky. 2003. "Boston Residents Should Decide Future of Biolab." Genewatch 17(1). http://www.gene-watch.org/genewatch/ articles/17-1Byravan.html.

CAE (Critical Art Ensemble). 1998. "Observations on Collective Cultural Action." Art Journal 57(2):72-85.

—. 2000a. "Performing a Cult." Drama Review 44(4):167-73.

. 2000b. "Recombinant Theatre and Digital Resistance." Drama Review 44(4):151-66.

CDC (Centers for Disease Control and Prevention). 2002. "CDC Releases New Bioterrorism Web Resources for Clinicians, Lab Professionals, Public.” Press release, January 18. http://www.cdc.gov/od/oc/media/pressrel/r020118.htm.

Chan, Sewell. 2006. "A Wider Inquiry, as More People Get Antibiotics and 2nd Apartment Is Checked." New York Times, February 24, 5.

Cohen, Hillel W., Robert M. Gould, and Victor W. Sidel. 2004. "The Pitfalls of Bioterrorism Preparedness: The Anthrax and Smallpox Experiences." American Journal of Public Health 94(10):1667-71.

Cox, Stan. 2005. “The \$256 Question.” AlterNet, July 25. http://www.alternet .org/story/23601/.

Davis, Mike. 2005. The Monster at Our Door: The Global Threat of Avian Flu. New York: New Press.

Enloe, Cynthia. 2000. Maneuvers: The International Politics of Militarizing Women's Lives. Berkeley: University of California Press.

Francis, David. 2005. "FDA Finalizes Food Bioterrorism Rule." GovExec.com: The Daily News Source of Government Executive Magazine, October 6. http:// www.govexec.com/dailyfed/1005/100605gsnl.htm.

Garrett, Laurie. 1994. The Coming Plague: Newly Emerging Diseases in a World Out of Balance. New York: Farrar, Straus \& Giroux.

Goldman, Adam. 2006. "Seven Tied to N.Y. Anthrax Patient Treated." Boston Globe, February 23. http://www.boston.com/yourlife/health/diseases/ articles/2006/02/23/officials_seek_to_ease_anthrax_fears/.

Gostin, Lawrence O., Jason W. Sopsin, Stephen P. Teret, Scott Burris, Julie Samia Mair, James G. Hodge, and Jon S. Vernick. 2002. "The Model State Emergency Powers Act: Planning for and Response to Bioterrorism and Naturally Occurring Infectious Diseases." Journal of the American Medical Association 288(5): 622-28.

GovExec.com. 2002. "In Other News: The Week's Top Stories from Other Publications." GovExec.com: The Daily News Source of Government Executive Magazine, May 8. http://www.govexec.com/homeland/email.htm.

Greenfield, Lawrence. 1997. Sex Offenses and Offenders: An Analysis of Data on 
Rape and Sexual Assault. NCJ-163392. Washington, DC: U.S. Department of Justice, Office of Justice Programs, Bureau of Justice Statistics.

Hawkins, Joan. 2005. "When Taste Politics Meets Terror: The Critical Art Ensemble on Trial." In 1000 Days of Theory, ed. Arthur Kroker and Marilouise Kroker. http://www.ctheory.net/articles.aspx?id $=482$.

Henderson, Schuyler. 2005. "Disregarding the Suffering of Others: Narrative, Comedy, and Torture." Literature and Medicine 24(2):181-208.

Hirsch, Robert. 2005. "The Strange Case of Steve Kurtz: Critical Art Ensemble and the Price of Freedom." Afterimage, May/June, 22-32.

Holland, Jesse J. 2004. "Senate OKs \$5.6B for Chemical Defense." NucNews, May 20. http://nucnews.net/nucnews/2004nn/0405nn/040520nn.htm\#320.

Inglesby, Thomas V., Tara O’Toole, Donald A. Henderson, John G. Bartlett, Michael S. Ascher, Edward Eitzen, Arthur M. Friedlander, et al., for the Working Group on Civilian Biodefense. 2002. "JAMA Consensus Statement: Anthrax as a Biological Weapon, 2002; Updated Recommendations for Management." Journal of the American Medical Association 287(17):2236-52.

Jaggar, Alison M. 2003. "Responding to the Evil of Terrorism." Hypatia 18(1): $175-82$.

Jernigan, John A., David S. Stephens, David A. Ashford, Carlos Omanaca, Martin S. Topiel, Mark Galbraith, Michael Tapper, et al. 2001. "Bioterrorism-Related Inhalation Anthrax: The First 10 Cases Reported in the United States." Emerging Infectious Diseases 7(6):933-44.

Kane, Stephanie. 1998. AIDS Alibis: Sex, Drugs, and AIDS in the Americas. Philadelphia: Temple University Press.

Kane, Stephanie, and Theresa Mason. 2001. "AIDS and Criminal Justice." Annual Review of Anthropology 30:457-79.

Kersten, Denise. 2004. "Three Years after Anthrax, Postal Response System Very Different." GovExec.com: The Daily News Source of Government Executive Magazine, September 10. http://www.govexec.com/dailyfed/0904/091004dk1 .htm.

Khalid, Nazery. 2005. "Improved Security = Lower Risks + Higher Costs: Passing on the Costs of Port Security." Paper presented at the Second Annual Maritime Security Forum in Kuala Lumpur, July 13-14.

King, Nicolas B. 2003. "The Influence of Anxiety: September 11, Bioterrorism, and American Public Health." Journal of the History of Medicine and Allied Sciences 58(4):433-41.

Landers, Susan J. 2002. "Smallpox Vaccine Hazards Dictate Cautious Approach." amednews.com: The Newspaper for America's Physicians 45, no. 31 (August 19). http://www.ama-assn.org/amednews/2002/08/19/hlsb0819.htm.

Mariner, Wendy K. 2003. "Public Health and Law: Past and Future Visions." Journal of Health Politics, Policy, and Law 28(2-3):525-52.

Mason, Carol. 2002. Killing for Life: The Apocalyptic Narrative of Pro-life Politics. Ithaca, NY: Cornell University Press. 
2005. "The Hillbilly Defense: Culturally Mediating U.S. Terror at Home and Abroad." NWSA Journal 17(3):39-63.

McGlinchey, David. 2004. "Senator Approves Plan to Redirect State Bioterrorism Funding." GovExec.com: The Daily News Source of Government Executive Magazine, June 2. http://www.govexec.com/dailyfed/0604/060204dl.htm.

Meinhardt, Patricia. 2005. "Water and Bioterrorism: Preparing for the Potential Threat to U.S. Water Supplies and Public Health." Annual Review of Public Health 26:213-37.

Nartker, Mike. 2005. "Biological Attack Likely by 2020, Report Warns." GovExec .com: The Daily News Source of Government Executive Magazine, January 14. http://www.govexec.com/dailyfed/0105/011405gsn2.htm.

Nursing Management. 2002. "Lifeline: Smallpox Vaccination." Nursing Management 33(9):32F.

Nuti, Paul. 2006. “Addressing Pandemic Preparedness." Anthropology News 47(3): 25.

Pentecost, Claire. 2005. "Reflections on the Case by the U.S. Justice Department against Steven Kurtz and Robert Ferrell.” Critical Art Ensemble Defense Fund, April 6. http://www.caedefensefund.org/reflections.html.

Peterson, Molly M. 2002. "Existing Technologies Could Bridge Information Gaps." GovExec.com: The Daily News Source of Government Executive Magazine, October 16. http://www.govexec.com/dailyfed/1002/101602tdl.htm.

Pringle, Peter. 1998. "Bioterrorism: America's Newest War Game.” Nation, November 9, 11-17.

Regalado, Antonio, Gary Fields, and Mark Schoofs. 2002. "FBI Makes Military Labs Key Focus on Anthrax." Wall Street Journal, February 12, A4.

Regis, Ed. 2004. “Our Own Anthrax: Dismantling America's Weapons of Mass Destruction." Harper's, July, 69-75.

SARS Commission. 2007. SARS Commission Report, vol. 3, chap. 5. http:// www.sarscommission.ca/report/v3-pdf/Vol3Chp5i.pdf.

Schneider, Rebecca. 2000. "Nomadmedia: On Critical Art Ensemble." Drama Review 44(4):120-31.

Schneider, Rebecca, and Jon McKenzie. 2004. "Keep Your EYES on the FRONT and WATCH YOUR BACK." Drama Review 48(4):5-10.

Schwabsky, Barry. 2005. "Patriotism as Paranoia: Steve Kurtz and the Critical Art Ensemble." Radical Philosophy 129 (January/February): 6-9.

Sheffield, Carole J. 2004. "Sexual Terrorism: The Social Control of Women.” In Oppression, Privilege, and Resistance: Theoretical Readings on Racism, Sexism, and Heterosexism, ed. Lisa Heldke and Peg O'Connor, 164-82. Boston: McGraw-Hill.

Smith, Stephen. 2005. "Bacterium Infected 3 at BU Biolab.” Boston Globe, January 19. http://www.boston.com/yourlife/health/diseases/articles/2005/01/19/ bacterium_infected_3_at_bu_biolab/.

Strohm, Chris. 2003. "Washington Postal Facility Anthrax-free, but Psychological Specter Looms." GovExec.com: The Daily News Source of Government Executive 
Magazine, November 12. http://www.govexec.com/dailyfed/1103/111203cl .htm.

Szalanski, Andrea. 2001-2. "Bioterrorism Copycats Target Planned Parenthood." Free Inquiry 22(1):32.

Thacker, Eugene. n.d. "Historical Background of the US Biowarfare Program." Critical Art Ensemble Defense Fund. http://www.caedefensefund.org/CAE _USbiowar.pdf.

U.S. Commission on Civil Rights. 2002. "Bioterrorism and Health Care Disparities." March 8. http://www.usccr.gov/pubs/biotrbrf/paper.htm.

Warrick, Joby. 2006. "The Secretive Fight against Bioterror." Washington Post, July 30. http://washingtonpost.com/wp-dyn/content/article/2006/07/29/ AR2006072900592_pf.html.

Webb, Greg. 2004. "Directive Defines Agency Roles in Battling Bioterrorism." GovExec.com: The Daily News Source of Government Executive Magazine, April 29. http://www.govexec.com/dailyfed/0404/042904gsnl.htm.

Weiss, Rick, and Susan Schmidt. 2001. "Capital Hill Anthrax Matches Army's Stocks: 5 Labs Can Trace Spores to Ft. Detrick." Washington Post, December 16. http://www.commondreams.org/headlines01/1216-03.htm.

Wilding, Faith. 2004. "Critical Art Ensemble: FBI Harassment of Artist and Scientist Continues." Journal of Visual Culture 3(3):317-19.

Youtt, Harry. 2003. "Artists of Denial and Avoidance after September 11th, 2001 (A Very Unorthodox View from the U.S.)." Conscionsness, Literature, and the Arts 4(3). http://www.aber.ac.uk/cla/archive/youtt.html. 